\title{
Effect of vermicompost tea on yield and nitrate reductase enzyme activity in saladette tomato
}

\author{
C. Márquez-Quiroz ${ }^{1 \dagger}$, S.T. López-Espinosa ${ }^{1}$, E. Sánchez-Chávez ${ }^{2 *}$, M.L. García-Bañuelos², E. De la \\ Cruz-Lázaro $^{1}$, and J.L. Reyes-Carrillo ${ }^{3}$
}

${ }^{1}$ División Académica de Ciencias Agropecuarias, Universidad Juárez Autónoma de Tabasco. Villahermosa, Tabasco. México. ${ }^{2}$ Centro de Investigación en Alimentación y Desarrollo A. C. Fracc. Vencedores del Desierto. Delicias, Chihuahua. México.

${ }^{3}$ Universidad Autónoma Agraria Antonio Narro. Torreón, Coahuila. México. *Corresponding author: esteban@ciad.mx

\begin{abstract}
In conventional agriculture, heavy doses of chemical fertilizers and pesticides are often used to improve the yield of various horticultural crops. These chemical fertilizers and pesticides cause health problems among consumers. Due to the adverse effects of chemical fertilizers, there is interest in the use of organic fertilizers. It has long been recognized that the rate-limiting step for nitrogen assimilation, the reduction of $\mathrm{NO}_{3}^{-}$to $\mathrm{NO}_{2}^{-}$catalyzed by nitrate reductase (NR), is highly regulated. An increase in the amount and activity of NR leads to a corresponding increase in the potential for nitrate reduction and confers a greater capacity for general amino-acid synthesis, protein synthesis or total nitrogen assimilation. The aim of the current experiment was to determine the effect of organic and conventional fertilizers on yield and nitrate reductase activity in saladette tomato.Tomato plants were grown under controlled greenhouse conditions and treated with either organic or conventional fertilizer. We evaluated five treatments: F1, sand + inorganic fertilizer; F2, sand + vermicompost tea; F3, a 1:1 mixture of sand: compost + vermicompost tea; F4, a 1:1 mixture of sand: vermicompost + vermicompost tea; and F5, a 2:1:1 mixture of sand: compost: vermicompost + vermicompost tea. The evaluated variables were yield, fruit size, number of fruits, fruit quality, chlorophyll content, and in vivo nitrate reductase enzyme activity. Fertilizer type strongly influenced the yield, fruit size, and fruit quality. The best organic fertilizer for tomatoes was sand + vermicompost tea. Tomatoes in this treatment group produced the second highest yield, the best $\mathrm{NO}_{3}{ }_{3}^{-}$assimilation, the greatest nitrate reductase enzyme activity, and the second highest organic foliar nitrogen content.
\end{abstract}

Keywords: Nitrogen metabolism, organic fertilizer, organic waste, quality, Solanum lycopersicum L.

${ }^{\dagger}$ These authors contributed equally to this work. 


\section{Introduction}

Livestock organic residues represent a serious ecological problem if they are not handled properly (Castillo et al., 2010). Agriculture, particularly cattle farming, is an important economic activity in the state of Coahuila, México. According to official statistics, Coahuila contains $1,708,887$ cattle; 79,050 hogs; 1,808,335 domestic fowls; 203,757 goats; 131,712 horses; and 86,621 sheep (INEGI., 2011), which generate significant quantity of waste. Although crop and livestock wastes are a potential source of contaminants causing human health problems, they can also provide the raw materials for an organic crop production and can have extensive applications.

One method for diminishing the environmental impact of organic waste materials is to compost or vermicompost them. The final products of these processes, composts and vermicomposts, can be used as sources of organic matter for soil amendment, sources of nutrients for soil fertilizer, or growing media constituents for soilless cultivation (González et al., 2010). Vermicompost tea (VCT), a waterbased vermicompost extract containing high levels of beneficial microbes and soluble nutrients (Edwards et al., 2010), has attracted the attention of growers and researchers in recent years. The most important reason for applying vermicompost tea is to supply microbial biomass, fine particulate organic matter, and soluble chemical components of vermicompost to plant surfaces and soils in a way that is not possible with solid vermicompost.

Analysis of the nutrient content of plant tissues is a widely used technique for assessing the nutritional status of plants; however, in some cases, plants growing in the same location differ in production due to the levels of fertilizer used, without showing differences in the concentration of elements (Bourret et al., 2009). The activity of the enzyme nitrate reductase (NR; EC 1.6.6.1), the first enzyme involved in the assimilation of $\mathrm{N}^{-\mathrm{NO}_{3}}$, is crucial for the development of plants and plays a key role in the assimilation of N (De la Haba et al., 2001). However, relatively little work has been undertaken to investigate the effect of vermicompost tea on the yield of vegetable crops in Mexico and on $\mathrm{N}-\mathrm{NO}_{3}{ }^{-}$assimilation.

We hypothesized that vermicompost tea as a fertilizer type would interact with productivity and $\mathrm{N}^{-\mathrm{NO}_{3}}$ assimilation in saladette tomatoes. Accordingly, the specific objective of this study was to determine the effect of organic and conventional fertilizer on saladette tomato yield and onnitrate reductase enzyme activity.

\section{Materials and Methods}

\subsection{Crop design}

Saladette tomato (Solanumly copersicum L.) cv. Anibal was seeded in cell flats (cell size $3 \times 3 \times 10$ $\mathrm{cm}$ ) filled with peat-lite mixture, which were placed on benches under greenhouse conditions for 5 weeks. The seedlings were then transplanted and grown under controlled conditions in an experimental greenhouse at Antonio Narro Agrarian Autonomous University (Universidad Autónoma Agraria Antonio Narro, UAAAN), Torreón, Coahuila, México. The experiment was conducted from October 2011 to April 2012. In this area, the climate is arid and the lands are intensively used for agriculture. The relative humidity was 60 $80 \%$ and the temperature range was $24 \pm 4{ }^{\circ} \mathrm{C}$, with extremes of $15{ }^{\circ} \mathrm{C}$ and $34{ }^{\circ} \mathrm{C}$ in the greenhouse. The experimental design was completely randomized with five treatments, the first of which served as the control group. Tomatoes were transplanted in individual 18-L pots. Each treatment was replicated 12 times.

The treatments consisted of five fertilizer types: $\mathrm{F} 1=$ sand + inorganic fertilizer; F2 $=$ sand + vermicompost tea at $2.5 \%$ concentration; F3 $=\mathrm{a} 1: 1$ mixture of sand: compost + vermicompost tea at $2.5 \%$ concentration; F4 $=a$ 1:1 mixture of sand: vermicompost + vermicompost 
tea at $2.5 \%$ concentration; and F5 $=\mathrm{a} 2: 1: 1$ mixture of sand: compost: vermicompost + vermicompost tea at $2.5 \%$ concentration. Table 1 shows the inorganic fertilizer used in the F1 treatment (Castellanos and Ojodeagua, 2009). For water supply we used drip irrigation in all treatments and the amount of water applied, according to the phonological stage of the crop, ranged from 0.35 to $1.9 \mathrm{~L} \mathrm{plant}^{-1}$ day $^{-1}$. The irrigation water was classified as low-salinity water and low sodium content $\left(\mathrm{C}_{1} \mathrm{~S}_{1}\right.$, with a sodium absorption ratio of 2.18); E.C: $1.05 \mathrm{dS} \mathrm{m}^{-1}, \mathrm{pH}: 7.8$; cations $\left(\mathrm{mmol} \mathrm{L}^{-1}\right): \mathrm{Ca}^{2+}=3.51, \mathrm{Mg}^{2+}=0.48, \mathrm{~K}^{+}=$ $0.22, \mathrm{Na}^{+}=2.71$ and anions $(\mathrm{mmol} \mathrm{L}-1): \mathrm{HCO}^{3-}=$ $3.12, \mathrm{Cl}^{-}=2.3$, and $\mathrm{SO}_{4}{ }^{2-}=2.62$. The substrates and vermicompost tea chemical characteristics are summarized in Table 2.
The fertilizers were applied gradually in the irrigation water over the entire growth period of the plants. The $\mathrm{pH}$ value of the solutions (inorganic and organic) was adjusted to 5.5 .

The manure-based vermicompost, which was provided by the vermicompost module of the UAAAN, consisted of separated horse and goat solids mixedin a 1:1 ratio by volume with alfalfa (Medicagos ativa L.), processed by earth worms (Eisenias pp.) in indoor beds for 90 days. The compost was provided by Max Compost ${ }^{\circledR}$. To prepare the VCT at $2.5 \%$ concentration, we followed the method recommended by Edwards et al. (2010), with a variation (Márquez-Quiroz et al., 2014). The final $\mathrm{pH}$ and E.C were adjusted to 5.5 and $2.5 \mathrm{dS} \mathrm{m}^{-1}$, respectively.

Table1. Nutrient solution for three developmental stages of tomato (Castellanos and Ojodeagua, 2009).

\begin{tabular}{cccc}
\hline Ion & $\begin{array}{c}\text { Stage 1 } \\
1^{\text {st }} \text { set }\end{array}$ & $\begin{array}{c}\text { Stage 2 } \\
1^{\text {nd }}-3^{\text {rd }} \text { set }\end{array}$ & $\begin{array}{c}\text { Stage 3 } \\
3^{\text {rd }}-5^{\text {th }} \text { set }\end{array}$ \\
\cline { 2 - 4 } & & meq L & \\
\hline $\mathrm{NO}_{3}^{-}$ & 6.0 & 8.0 & 10.0 \\
$\mathrm{NH}_{4}{ }^{-}$ & 0.5 & 0.5 & 0.5 \\
$\mathrm{H}_{2} \mathrm{PO}_{4}^{-}$ & 1.5 & 1.5 & 1.5 \\
$\mathrm{~K}^{+}$ & 3.5 & 5.5 & 7 \\
$\mathrm{Ca}^{2+}$ & 8.0 & 8.0 & 8.0 \\
$\mathrm{Mg}^{2+}$ & 2.0 & 3.0 & 4.0 \\
$\mathrm{SO}_{4}^{2-}$ & 3.0 & 4.0 & 6.0 \\
$\mathrm{HCO}_{3}^{-}$ & 1.0 & 1.0 & 1.0 \\
$\mathrm{Na}^{+}$ & $<5.0$ & $<5.0$ & $<5.0$ \\
$\mathrm{Cl}^{-}$ & 1.0 & 1.0 & 1.0 \\
\hline $\mathrm{EC}\left(\mathrm{dS} \mathrm{m}{ }^{-1}\right)$ & 1.4 & & 2.2 \\
\hline
\end{tabular}

$\mathrm{EC}=$ electrical conductivity 
Table2. Mineral elements provided by each fertilizer source during the production cycle.

\begin{tabular}{|c|c|c|c|c|c|c|c|c|c|c|c|}
\hline \multirow[b]{2}{*}{ Substrate } & $\mathrm{N}$ & P & K & $\mathrm{Ca}$ & $\mathrm{Mg}$ & $\mathrm{Na}$ & $\mathrm{Fe}$ & $\mathrm{Zn}$ & $\mathrm{Mn}$ & \multirow[t]{2}{*}{$\mathrm{OM}$} & BD \\
\hline & \multicolumn{6}{|c|}{$\left(\mathrm{gpot}^{-1}\right)$} & \multicolumn{3}{|c|}{$\left(\mathrm{mg} \operatorname{pot}^{-1}\right)$} & & $\begin{array}{c}(\mathrm{g} \\
\left.\mathrm{cm}^{-3}\right)\end{array}$ \\
\hline F3 & 151.8 & 75.0 & 211.7 & 551.9 & 59.2 & 35.9 & 37296.0 & 1638.0 & 1008.0 & 29.2 & 1.2 \\
\hline $\mathrm{F} 4$ & 80.0 & 9.4 & 55.4 & 436.0 & 37.8 & 6.3 & 44667.0 & 2079.0 & 1322.0 & 10.5 & 1.2 \\
\hline F5 & 115.9 & 42.2 & 133.6 & 493.9 & 48.5 & 21.1 & 40981.5 & 1858.5 & 1165.5 & 19.9 & 1.2 \\
\hline
\end{tabular}

\begin{tabular}{|c|c|c|c|c|c|c|c|c|c|c|}
\hline \multirow[b]{4}{*}{ VCT } & \multirow[t]{2}{*}{$\mathrm{N}$} & \multirow[t]{2}{*}{$P$} & \multirow[t]{2}{*}{$\mathrm{K}$} & \multirow[t]{2}{*}{$\mathrm{Ca}$} & \multirow[t]{2}{*}{$\mathrm{Mg}$} & \multirow[t]{2}{*}{$\mathrm{Na}$} & \multirow[t]{2}{*}{$\mathrm{Fe}$} & \multirow[t]{2}{*}{$\mathrm{Zn}$} & \multirow[t]{2}{*}{ Mn } & \multirow[t]{2}{*}{$\begin{array}{c}\text { VCT } \\
\text { applied }\end{array}$} \\
\hline & & & & & & & & & & \\
\hline & \multicolumn{6}{|c|}{$\left(\right.$ g cycle $\left.^{-1}\right)$} & \multicolumn{3}{|c|}{$\left(\mathrm{mg} \mathrm{cycle}^{-1}\right)$} & $\left(\right.$ L cycle $\left.^{-1}\right)$ \\
\hline & 213.8 & 126.2 & 182.9 & 831.8 & 193.2 & 51.5 & 61.8 & 12.9 & 40.7 & 77.3 \\
\hline
\end{tabular}

$\mathrm{OM}=$ organic matter; $\mathrm{BD}=$ bulkdensity $; \mathrm{VCT}=$ vermicompost tea.

\subsection{Fruit sampling}

Tomatoes were usually harvested weekly at the mature red stage. Yield was determined by counting and weighing all fruit on each plant. Fruit size was determined by measuring the equatorial diameter, using the Mexican standard norm (NMX-FF-031, 1997). The soluble solids concentration (SSC) of a composite juice sample was measured with a handheld refractometer.

\subsection{Plant sampling}

Leaf samples were taken from plants with fully expanded leaves of the same size. Leaves were removed from a zone at approximately one-third of the total height of the plant, during flowering ( 77 days after planting, DAP) and 4 weeks later (105 DAP). Leaves were disinfected with nonionic detergent at $1 \%$ (Wolf, 1982), rinsed three times in distilled water, and blotted on filter paper. At each sampling, fresh leaf matter was used for the NR assay and analysis of foliar pigments; a subsample was dried in a forced-air oven at $70{ }^{\circ} \mathrm{C}$ for 24 hours, ground in a Wiley mill, and placed in a plastic bag for further analysis of organic $\mathrm{N}$.

\subsection{Plant analysis}

The in vivo NR activity was determined using an adaptation of the in vivo NR assay of Jaworski (1971). The NR activity was expressed as $\mu \mathrm{mol}$ $\mathrm{NO}_{2}^{-} \mathrm{g}^{-1}$ fresh weight (fw) $\mathrm{h}^{-1}$. Chlorophyll was extracted and measured following Wellburn (1994). Chlorophyll content was expressed as $\mu \mathrm{g}$ pigment $\mathrm{cm}^{-2}$. The organic $\mathrm{N}$ content was determined using the Kjeldahl method (Wolf, 1982).

\subsection{Statistical analysis}

Standard analysis-of-variance techniques were used to assess the significance of treatment means. Differences between treatment means were compared using the LSD at the 0.05 probability level. Levels of significance are represented by * at $p<0.05, * *$ at $p<0.01, * * *$ at $p<0.001$, and NS for not significant. 
Table3. Comparison of means for tomatoes developed with conventional and organic fertilizers.

\begin{tabular}{|c|c|c|c|c|c|c|c|}
\hline \multirow[t]{2}{*}{ Fertilizer } & PD & ED & $\mathrm{PT}$ & \multirow{2}{*}{$\begin{array}{l}\mathrm{SSC} \\
\left({ }^{\circ} \mathrm{Bx}\right)\end{array}$} & \multirow{2}{*}{$\begin{array}{l}\text { FW } \\
(\mathrm{g})\end{array}$} & \multirow[t]{2}{*}{$\mathrm{NF}$} & \multirow{2}{*}{$\begin{array}{c}\mathrm{Y} \\
\left(\mathrm{Mg} \mathrm{ha}^{-1}\right)\end{array}$} \\
\hline & & $(\mathrm{cm})$ & & & & & \\
\hline F1 & $6.4 \mathrm{a}$ & $5.3 \mathrm{a}$ & $0.7 \mathrm{a}$ & $3.6 \mathrm{~b}$ & $99.2 \mathrm{a}$ & $20 \mathrm{a}$ & $76.5 \mathrm{a}$ \\
\hline F2 & $6.5 \mathrm{a}$ & $5.1 \mathrm{ab}$ & $0.7 \mathrm{a}$ & $3.9 \mathrm{~b}$ & $96.6 \mathrm{a}$ & $18 \mathrm{ab}$ & $66.9 \mathrm{ab}$ \\
\hline F3 & $6.0 \mathrm{~b}$ & $5.0 \mathrm{bc}$ & $0.7 \mathrm{a}$ & $4.6 \mathrm{a}$ & $84.7 \mathrm{~b}$ & $14 \mathrm{~cd}$ & $48.9 \mathrm{~cd}$ \\
\hline F4 & $6.2 \mathrm{~b}$ & $5.0 \mathrm{bc}$ & $0.7 \mathrm{a}$ & $4.5 \mathrm{a}$ & $97.4 \mathrm{a}$ & $16 b c$ & $54.3 \mathrm{bc}$ \\
\hline F5 & $6.1 \mathrm{~b}$ & $4.9 \mathrm{c}$ & $0.7 \mathrm{a}$ & $4.7 \mathrm{a}$ & $83.1 \mathrm{~b}$ & $12 \mathrm{~d}$ & $37.0 \mathrm{~d}$ \\
\hline Significance & $* *$ & $*$ & NS & $* * *$ & $* *$ & $* * *$ & $* * *$ \\
\hline
\end{tabular}

$\mathrm{PD}=$ polar diameter; $\mathrm{ED}=$ equatorial diameter; $\mathrm{PT}=$ pericarp thickness; $\mathrm{SSC}=$ soluble solids content; $\mathrm{FW}=$ fruit weight; $\mathrm{NF}=$ number of fruits; $\mathrm{Y}=$ yield; The results of LSD test is represented with lower case letters; ***_***_significant differences at $p<$ $0.001, p<0.01$ and $p<0.05$, respectively, NS $=$ not significant.

\section{Results and Discussion}

\subsection{Yield}

Vermicompost contains a substantial amount of humic acids that stimulate plant growth and yield (Arancon et al., 2007). The highest total yield was recorded for the F1 treatment (Table 3); this treatment exceeded by $32.3 \%$ the overall average of $51.8 \mathrm{Mg} \mathrm{ha}^{-1}$ obtained with organic fertilizers. The maximum yield obtained using inorganic fertilizers, compared with the organic fertilizers, was assessed by De la Cruz-Lazaro et al. (2010). Stanhill (1990), mentions that in organic agriculture the yield is $10 \%$ to $30 \%$ lower than the yield achieved by conventional farming. The lower yield can be offset by the higher price that organic tomatoes command, which is 5.8 times the price of tomatoes grown under conventional management (De la Cruz-Lazaro et al., 2010). It means that the organic tomato production increases the cost-benefit relationship (Rodríguez et al., 2008).

Table 3 shows that the F2 treatment provided the maximum organic fruit yield, $66.9 \mathrm{Mg} \mathrm{ha}^{-1}$, followed by the F4 treatment. (Arancon et al., 2007) reported that humic, fulvic, and other organic acids extracted or produced by microorganisms in VCT may promote the vegetative development of plants and increase the yield. This finding may explain the results obtained by Martinez et al. (2002), who concluded that compost tea contains a compound with molecular structure and biological activity analogous to auxins. Leachate from well-decomposed compost has been shown to contain a cytokinin-like substance, derived from the hydrolysis of cyanogenic glucosides by the enzyme $\beta$-glucosidase, which is produced by microbes (Arthur et al., 2001). Although phytohormones or growth regulators in VCT were not measured in this study, we suggest that they may play an important role in plant response.

The greatest number of fruits per plant was obtained in the F1 treatment group (Table 3). The numbers of fruits obtained using organic fertilizer were $10 \%, 30 \%, 20 \%$, and $40 \%$ less under the F2, F3, F4, and F5 treatments, respectively, than the number of fruits obtained using the F1 treatment. Similar results have been reported by Rodríguez et al. (2008), who obtained $22.9 \%$ and $31.2 \%$ fewer fruits from two tomato hybrids using 
mixtures of sand and vermicompost. Fruit size was based on the equatorial diameter, using the Mexican standard norm (NMX-FF-031, 1997).

The F3, F4, and F5 treatments produced small tomatoes (Table 3), whereas the F1 and F2 treatments resulted in medium fruit size. No statistical difference was detected for the thickness of the pericarp. The average weight of the fruits under the F2 and F3 treatments was not affected. Coleto (1995) mentions that after cell division, photoassimilates begin to accumulate, affecting growth and fruit weight. It is therefore likely that in the organic fertilizer groups (F2 and F4), there was reduced demand for assimilates and other growth hormones in apical tissues, which favored the content of cytokinins and the accumulation of photoassimilates in fruit. The average SSC under organic fertilizer use increased $22.9 \%$ relative to the value obtained in the $\mathrm{F} 1$ treatment group. Increases in SSC in fruit of organic plants, in contrast, likely result from the interaction between reduced fruit water content, increased ion content, and maintained hexose accumulation.This result confirms that the use of organic fertilizers produces fruits with better quality in terms of soluble solids, as a tomato intended for fresh consumption must contain more than $4.0^{\circ} \mathrm{Bx}$ (De la Cruz-Lazaro et al., 2010). Diez (1995) mentioned that a tomato for processing or fresh consumption must have an SSC of at least $4.5{ }^{\circ} \mathrm{Bx}$. The F3, F4, and F5 treatments produced tomatoes with over $4.5^{\circ} \mathrm{Bx}$ that were suitable for fresh consumption and for use by industry.

Table 4. Effect of conventional and organic fertilizers on chlorophyll content, organic $\mathrm{N}$ content in leaves and in vivo endogenous $\mathrm{NR}$ activity and $\mathrm{NR}$ activity in presence of $\left.50 \mathrm{mM} \mathrm{NO}_{3}^{-}\left(\mathrm{NR}+\mathrm{NO}_{3}^{-}\right), 20 \mathrm{mM} \mathrm{Mo}^{-} \mathrm{NR}+\mathrm{Mo}\right), 50 \mathrm{mM} \mathrm{NO}_{3}^{-}$, and $20 \mathrm{mM}$ Mo $\left(\mathrm{NR}+\mathrm{NO}_{3}^{-}+\mathrm{Mo}\right)$ in leaves of tomato.

\begin{tabular}{|c|c|c|c|c|c|c|}
\hline \multirow[t]{2}{*}{ Fertilizer /77 DAP } & \multirow{2}{*}{$\begin{array}{l}\mathrm{N} \\
(\%)\end{array}$} & \multirow{2}{*}{$\begin{array}{l}\text { Chla }+b \\
(\mu \mathrm{g} \mathrm{cm}- \\
\left.{ }^{2}\right)\end{array}$} & NR endogenous & $\mathrm{NR}+\mathrm{NO}_{3}^{-}$ & $\mathrm{NR}+\mathrm{Mo}$ & $\mathrm{NR}+\mathrm{NO}_{3}^{-}+\mathrm{Mo}$ \\
\hline & & & \multicolumn{4}{|c|}{$\left[\mu \mathrm{mol}\left(\right.\right.$ nitrates) $\mathrm{g}^{-1}$ (f.w) $\left.\mathrm{h}^{-1}\right]$} \\
\hline F1 & $3.4 \mathrm{~b}^{*}$ & $0.033 \mathrm{a}$ & $3.4 \mathrm{c}$ & $26.7 \mathrm{a}$ & $20.9 \mathrm{e}$ & $29.8 \mathrm{c}$ \\
\hline F2 & $3.9 \mathrm{a}$ & $0.027 \mathrm{~d}$ & $7.0 \mathrm{~b}$ & $22.5 \mathrm{~d}$ & $23.2 \mathrm{~d}$ & $23.0 \mathrm{e}$ \\
\hline F3 & $3.3 \mathrm{c}$ & $0.026 \mathrm{e}$ & $11.7 \mathrm{a}$ & $23.5 \mathrm{c}$ & $28.6 \mathrm{c}$ & $25.1 \mathrm{~d}$ \\
\hline $\mathrm{F} 4$ & $2.7 \mathrm{e}$ & $0.032 \mathrm{~b}$ & $2.6 \mathrm{~d}$ & $20.8 \mathrm{e}$ & $37.7 \mathrm{a}$ & $38.1 \mathrm{~b}$ \\
\hline F5 & $3.1 \mathrm{~d}$ & $0.029 \mathrm{c}$ & $0.3 \mathrm{e}$ & $23.9 \mathrm{~b}$ & $31.8 \mathrm{~b}$ & $38.7 \mathrm{a}$ \\
\hline \multicolumn{7}{|l|}{ Fertilizer/105 DAP } \\
\hline F1 & $2.1 \mathrm{~d}$ & $0.032 \mathrm{~b}$ & $0.6 \mathrm{c}$ & $32.9 \mathrm{~b}$ & $24.6 \mathrm{~d}$ & $41.3 \mathrm{c}$ \\
\hline $\mathrm{F} 2$ & $2.6 \mathrm{~b}$ & $0.033 \mathrm{a}$ & $1.0 \mathrm{~b}$ & $35.7 \mathrm{a}$ & $22.8 \mathrm{e}$ & $32.4 \mathrm{e}$ \\
\hline F3 & $2.7 \mathrm{a}$ & $0.027 \mathrm{e}$ & $0.3 \mathrm{e}$ & $19.6 \mathrm{e}$ & $30.4 \mathrm{a}$ & $45.10 \mathrm{a}$ \\
\hline F4 & $2.5 \mathrm{c}$ & $0.030 \mathrm{c}$ & $0.4 \mathrm{~d}$ & $22.9 \mathrm{~d}$ & $28.1 \mathrm{c}$ & $33.8 \mathrm{~d}$ \\
\hline F5 & $2.1 \mathrm{~d}$ & $0.029 \mathrm{~d}$ & $1.4 \mathrm{a}$ & $25.4 \mathrm{c}$ & $28.4 \mathrm{~b}$ & $44.9 \mathrm{~b}$ \\
\hline
\end{tabular}

*The results of the LSD test are represented with lower case letters. 


\subsection{Organic $N$ content and foliar pigments}

Chlorophyll concentrations are related to $\mathrm{N}$ fertilizer and the $\mathrm{N}$ foliar content (Haboudane et al., 2002). In the present study, the organic $\mathrm{N}$ leaf content in the F1, F2, F3, and F5 treatments was within the optimal level at 77 DAP, while at 105 DAP, only leaves from the F1 and F5 treatments showed low levels of organic N (Table 4) (Mills et al., 1996). The total chlorophyll content $(\mathrm{a}+\mathrm{b})$ at 77 DAP was within the optimum level reported by Moreno et al. (1999) for the F1 and F4 treatments, whereas at 105 DAP, the optimum total chlorophyll content was recorded in the F1, F2, and F4 treatments.

\subsection{In vivo NR activity}

One of the major and limiting stages of $\mathrm{NO}_{3}$ assimilation is NR activity (De la Haba et al., 2001). The highest in vivo assay values were found inthe F2 and F3 treatmentsat 77 DAP, showing a 95.7\% increase over the lowest values, which were found in the F5 treatment at 77 DAP (Table 4). At 105 DAP, the highest in vivo assay values were found in the F2 and F5 treatments, showing a 70\% increase over the lowest values, which were recorded for the F3 treatment. One of the principal factors regulating both the increase in de novo NR synthesis and NR activity is the presence of $\mathrm{NO}_{3}^{-}$(Crawford, 1995). With respect to the NR activity in the presence of $\mathrm{NO}_{3}^{-}$and molybdenum (Mo), the plants require this ion and microelement; Mo is a cofactor for activating NR and for converting nitrates to nitrites (Zimmer and Mendel, 1999). Our results coincide with those obtained by Crawford (1995) and Villora et al. (2002), who found that the NR enzymatic activity was modified by altering the concentrations of $\mathrm{NO}_{3}^{-}$and $\mathrm{Mo}$ in the growth medium. The values of NR activity induced by simultaneous presence of $\mathrm{NO}_{3}^{-}$and Mo showed the general need of plants for both $\mathrm{NO}_{3}$ and for $\mathrm{Mo}$, to activate the enzyme and make use of cellular N. The presence of flowers and fruits in some plants accelerates and increases the endogenous NR activity (Carelli et al., 2006). At 105 DAP, NR activity produced higher induction of
$\mathrm{NO}_{3}^{-}, \mathrm{Mo}$, and the combination of both factors, while endogenous NR activity diminished (Table 4). This occurred presumably because the crop was in the maturation phase; furthermore, the NR activity varied according to the physiological age of the tissue, levels of water, light intensity, $\mathrm{N}$ source, temperature, and the levels of Mo, iron, and sodium (Tarakcioglu and Inal, 2002). An increase in the amount and activity of NR leads to a corresponding increase in the potential for nitrate reduction and confers a greater capacity for general aminoacid synthesis, protein synthesis, or total $\mathrm{N}$ assimilation (Ruiz et al., 2000).

\section{Conclusion}

We conclude that the best source of organic fertilizer for tomatoes was the F2 treatment, sand + VCT. It produced the second highest yield, the maximum assimilation of $\mathrm{NO}_{3}^{-}$, the highestlevel of NR activity, and the second highest organic $\mathrm{N}$ leaf content.

\section{Acknowledgements}

The present experiment was supported by the CONACYT scholarship (214907). The first author is grateful to the team of the Plant Physiology and Nutrition Laboratory of the Research Center for Food and Development A. C (Centro de Investigación en Alimentación y Desarrollo A. C) Delicias, Chihuahua unit for the facilities provided.

\section{References}

Arancon, N.Q., Edwards, C.A., Dick, R., Dick, L. 2007. Vermicompost tea production and plant growth impacts. Biocycle. 48, 51-52.

Arthur, G.D., Jäger, A.K., Van Staden, J. 2001. The release of cytokinin-like compounds from Gingko biloba leaf material during composting. Environ Exp. Bot. 45, 55-61. 
Bourret, M.M., Brummer, J.E., Leininger, W.C. 2009. Establishment and Growth of Two Willow Species in a Riparian Zone Impacted by Mine Tailings. J Environ. Qual. 38, 693-701.

Carelli, M.L.C., Fahl, J.I., Ramalho, J.D.C. 2006. Aspects of nitrogen metabolism in coffee plants. Braz. J. Plant Physiol. 18, 9-21.

Castellanos, J.Z., Ojodeagua, J.L., 2009. Formulación de la solución nutritiva. In: Manual de producción horticola en invernadero. J. Z Castellanos (Ed.). P 131-156. Intagri. México.

Castillo, H., Ojeda, D., Dominguez, D., Hernández, A. 2010. Effect of Californian Red Worm (Eisenia foetida) on the Nutrient Dynamics of a Mixture of Semicomposted Materials Chil. J. Agr. Res. 70, 465-473.

Coleto, M.J., 1995. Crecimiento y desarrollo de las especies frutales. Mundi-Prensa. 168 pp.

Crawford, N.M. 1995. Nitrate: nutrient and signal for plant growth. The Plant Cell Online. 7, 859-868.

De la Cruz-Lazaro, E., Osorio-Osorio, R., MartinezMoreno, E., del Rio, A.J.L., Gomez-Vazquez, A., Sanchez-Hernandez, R. 2010. Use of composts and vermicomposts for organic production of tomato in greenhouses. Interciencia. 35, 363-368.

De la Haba, P., Agüera, E., Benítez, L., Maldonado, J.M., 2001. Modulation of nitrate reductase activity in cucumber (Cucumis sativus) roots. Plant Sci. 161, 231-237.

Diez, N. 1995. Tipos varietales. In: El cultivo del tomate. Nuez, F. (ed). Bilbao, España, Ediciones Mundiprensa. p. 93-129.

Edwards, C.A., Askar, A., Vasko-Bennett, M., Arancon, N. 2010. The Use and Effects of Aqueous Extracts from Vermicomposts or Teas on Plant Growth and Yields. In: Edwards, C.A., Arancon, N.Q.,
Sherman, R.L. (eds.), Vermiculture Technology: Earthworms, Organic Wastes, and Environmental Management. CRC Press, pp. 235-248.

González, M., Gomez, E., Comese, R., Quesada, M., Conti, M. 2010. Influence of organic amendments on soil quality potential indicators in an urban horticultural system. Bioresource Technol. 101, 8897-8901.

Haboudane, D., Miller, J.R., Tremblay, N., ZarcoTejada, P.J., Dextraze, L. 2002. Integrated narrow-band vegetation indices for prediction of crop chlorophyll content for application to precision agriculture. Remote Sens Environ. 81, 416-426.

INEGI., 2011. Instituto Nacional de Estadística y Geografía. Anuario de estadísticas por entidad federativa. México. 596 pp. http://www. inegi.org.mx/prod_serv/contenidos/espanol/ bvinegi/productos/integracion/pais/aepef/2011/ Aepef2011.pdf. (24/05/2013).

Jaworski, E.G. 1971. Nitrate reductase assay in intact plant tissues. Biochem. Bioph. Re. Co. 43, 12741279.

Márquez-Quiroz, C., Cano-Ríos, P., MorenoReséndez, A., Figueroa-Viramontes, U., SánchezChávez, E., De la Cruz-Lazaro, E., RobledoTorres, V. 2014. Efecto de la fertilización orgánica sobre el rendimiento y contenido nutricional de tomate saladette en invernadero. ITEA 110 (1): DOI: 10.12706/itea.2013.030

Martinez, I., Sosa, F.C., Saavedra, A., Hernandez, M. 2002. Extraction of auxin-like substances from compost. Crop Research-Hisar. 24, 323-327.

Mills, H.A., Jones, B.J.J., Wolf, B. 1996. Plant Analysis Handbook II: A Practical Sampling, Preparation, Analysis, and Interpretation Guide. Micro-Macro Publishing, 
Moreno, D.A., Villora, G., Ruiz, J.M., Romero, L. 1999. Optimun range in tomato cultivars: III. Physiological parameters. Phyton-Int J Exp Bot. 64, 57-62.

NMX-FF-031, 1997. Normas Mexicanas. Productos alimenticios no industrializados, para su consumo humano-Hortalizas frescas-tomate(Lycopersicun esculentum Mill.)-Especificaciones. http://200.77.231.100/work/normas/nmx/1998/ nmx-ff-031-1998.pdf.

Rodríguez, D.N., Cano,R. P., Figueroa, V.U., Palomo, G.A., Favela, C.E., Álvarez, R.V., Márquez, H.C., Moreno, R.A. 2008. Producción de tomate en invernadero con humus de lombriz como sustrato. Rev. Fitotec. Mex. 31, 265-272.

Ruiz, J.M., Moreno, D.A., Víllora, G., Olivares, J., García, P.C., Hernández, J., Romero, L. 2000. Nitrogen and phosphorus metabolism and yield of capsicum plant (Capsicum annuum L. cv. Lamuyo) in response to increases in NK fertilization. Commun. Soil Sci. Plan. 31, 2345-2357.

Stanhill, G. 1990. The comparative productivity of organic agriculture. Agri. Ecosyst. Environ. 30, 1-26.
Tarakcioglu, C., Inal, A. 2002. Changes induced by salinity, demarcating specific ion ratio $(\mathrm{Na} / \mathrm{Cl})$ and osmolality in ion and proline accumulation, nitrate reductase activity, and growth performance of lettuce. J. Plant Nutr. 25, 27-41.

Víllora, G., Moreno, D.A., Romero, L. 2002. Response of Eggplant to Nitrogen Supply: Molybdenum-Nitrate Relationships. Biol. Plantarum. 45, 621-623.

Wellburn, A.R. 1994. The Spectral Determination of Chlorophylls a and b, as well as Total Carotenoids, Using Various Solvents with Spectrophotometers of Different Resolution. J. Plant Physiol. 144, 307-313.

Wolf, B. 1982. A comprehensive system of leaf analyses and its use for diagnosing crop nutrient status. Commun. Soil Sci. Plan. 13, 1035-1059.

Zimmer, W., Mendel, R. 1999. Molybdenum Metabolism in Plants. Plant Biology. 1, 160168. 